\title{
CELL SUSPENSIONS, CELL CULTURES, AND TISSUE SLICES - IMPORTANT METABOLIC IN VITRO SYSTEMS
}

\author{
Kateřina Červenková, ${ }^{\mathrm{a}}$ Marie Belejova, ${ }^{\mathrm{b}}$ Jaroslav Veselý, ${ }^{\mathrm{a}}$ Zdeněk Chmela, ${ }^{\mathrm{a}}$ Miroslav Rypka, ${ }^{\mathrm{a}}$ \\ Jitka Ulrichová, ${ }^{\mathrm{c}}$ Martin Modrianský, ${ }^{\mathrm{c}}$ Patrick Maurel ${ }^{\mathrm{d}}$
}

\author{
a Department of Pathological Physiology, Medical Faculty, Palacký University \\ b Department of Pharmacology, Medical Faculty, Palacký University \\ c Department of Medical Chemistry and Biochemistry, Medical Faculty, Palacký University, Hněvotínská 3, \\ 77515 Olomouc, Czech Republic \\ d INSERM U128, CNRS, Montpellier, France
}

Received: December 9, 2001

Key words: $\quad$ In vitro systems / Tissue slices / Metabolism / Viability tests

In vitro subcellular and cellular systems have important and irreplaceable roles in the metabolic investigations that precede the development of new potential drugs. Of these model systems, tissue slices are probably the nearest to in vivo conditions. From the experimental and complexity points of view, perfused organs lie midway between tisssue slices and whole organism. Preparation and working with liver slices is quick and easy, and, excess material can be cryopreserved and stored untill the next experiment. Slices can be prepared from a wide variety of organs and it is possible to co-incubate them. Another important feature is the possibility of interspecies comparison of slices. Different experiments can be run both in the short-term as well as long-term incubations. Each in vitro system has an important place for example, in the development of new medicaments. It is therefore important to compare and supplement experimental results from different in vitro systems when extrapolating to in vivo situations is done.

\section{INTRODUCTION}

Cell suspensions, cell cultures and tissue slices represent in vitro model systems characterized by preserved integrated cell metabolism. Compared to subcellular models, these systems have several advantages. Firstly, enzyme cofactors need not be added to an incubation system. Second, the risk of unstable enzymes loss is minimized. Third, intracellular compartment integrity is maintained and metabolic reactions remain interconnected and occur naturally, this is difficult to obtain during experiments on sub-cellular levels.

\section{Hepatocyte suspensions}

Isolated hepatocytes and hepatocyte suspensions are a successful example of a cellular model that is used routinely during the development of new drugs and in the investigation of metabolic or toxic effects of xenobiotics. The following summarizes important points that should be considered when utilizing this model.

Hepatocytes are usually obtained after a two-step collagenase action on the liver tissue. Collagenase disrupts intercellular contacts and communication systems. However, preservation of normal intercellular contacts is considered critical for preservation of some important features of differentiated cells ${ }^{1}$. Remarkably the cells lose their polar character and change shape after collagenase digestion. Proteolysis also damages the enzyme and receptor apparatus of cells. It impairs their biophysical characteristics and transport capabilities as well. Nevertheless, the cells are capable of repairing membrane defects and may preserve the majority of their functions.

Utilization of hepatocytes in suspension is limited by their survival period during which they can exhibit metabolic activity. This is why cell suspensions can be used only for a period of four to six hours. Also the number of samples tested is limited with one hepatocyte preparation.

\section{Hepatocyte cultures}

If hepatocytes in suspensions survive only for hours and tissue slices last a few days, liver cell cultures can be maintained for weeks. Cell cultures are different from tissue slices in that they represent only chosen cell types, most typically only one type, whose isolation is technically and time demanding. It is also necessary to prevent them from overgrowing other cell types and protect them against contamination and infection.

Cell-to-cell interactions are very different in cell cultures. Confluent cell monolayers are typical by their abnormal cell surface-to-cell volume ratio or cell surface-to-protein content ratio. The cells have a much larger contact area with their surroundings than they have in vivo or in slices.

Twenty-four hours after the hepatocytes have created a monolayer, a rapid decrease in cytochrome $\mathrm{P} 450$ occurs in the cells and this may continue until cyto- 
chromes P450 expression reaches its basal level which is gene- and species-dependent. Although this may not be a feature of a dedifferentiation and it probably reflects the absence of proper inducers in incubation media, the cytochrome $\mathrm{P} 450$ spectrum in a final cell culture quite often differs from that of a fresh tissue.

The obvious advantage of cell cultures is the simplification of the experimental system. Moreover, they provide opportunity for running slow and long lasting experiments such as slow metabolic processes or gene induction that may require periods of several days ${ }^{1-5}$.

The main drawback of cell cultures is, that due to dedifferentiation, they cannot be used as a reliable method for systematic evaluation of interspecies differences in xenobiotic metabolism - the information of most value when extrapolating results from animals to humans.

Hepatocyte culture preparation and incubation. Hepatocytes are obtained by collagenase liver perfusion as is the case for cell suspensions. Destined for culture, hepatocytes are separated from other cell types by differential centrifugation, checked for viability and then seeded onto collagen-coated culture dishes and thereon maintained in a humidified incubator at $37^{\circ} \mathrm{C}$ with $95 \%$ oxygen and $5 \% \mathrm{CO}_{2}$ atmosphere. Most frequently a single layer of collagen is used. Though some investigators also use a "sandwich" where the formed monolayer of hepatocytes is topped with another layer of collagen or similar matrix ${ }^{6}$ or, hepatocytes are co-cultured with other cell type, eg. fibroblasts. The seeded hepatocytes are allowed to attach and stabilize for typically three to four hours in a culture medium which is then replaced by a fresh one during which process the dead and unattached cells are discarded. Quite often the culture is allowed a further 24 hours of stabilization following the medium exchange and prior to any experiments. Cultures are stable for at least a week with obligatory medium exchange every 24 hours. Occasional colonies of fibroblasts may appear in the culture after two or three days as a result of incomplete separation from hepatocytes in the centrifugation step during isolation. This has, however, a negligible effect on the culture behavior.

The lifetime of the culture may be extended for several weeks when appropriate media supplements, such as growth factors and/or cytokines, are added. This however requires previous experimentation to determine their correct concentration. Generally these cultures exhibit only basal levels of cytochrome P450 expression but still possess the ability to respond to cytochrome P450 inducers ${ }^{1}$. Cryopreservation of a culture is impractical for storage reasons, bulky culture dishes per low number of cells, and also due to low cell survival after thawing. Any isolated cells unused for seeding can be cryopreserved in larger quantities in dedicated freeze bags, although, cell viability after thawing is again low and cell functions rapidly deteriorate, typically within hours ${ }^{7,8}$.

\section{Tissue slices}

Recently, fully automated, precise and reliable slicers have been introduced to prepare tissue slices for reproducible metabolic studies. In the nineteen eighties C. L. Krumdiek designed a fully automated microtome for the preparation of undamaged, precision-cut native slices ${ }^{9,10}$. Since the invention of this technique, tissue slicing has undergone a renaissance and the European Center for the Validation of Alternative Methods (ECVAM) finds that this method contributes to the reduction of the number of laboratory animals required for research ${ }^{2}$.

Currently, tissue slices are mainly used to study how natural and synthetic substances are metabolised. Focusing on the liver, tissue slicing is obvious since this organ exhibits the highest xenobiotic turnover in the body. Slices are also used for more classical studies such as the investigation of different areas of organ physiology. They provide excellent opportunities to follow the

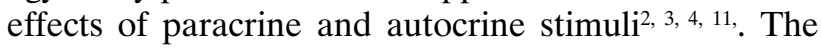
latest use of tissue slices is in clinical practice as a diagnostic technique utilized in organ transplantation ${ }^{12}$.

From the experimental and complexity points of view, a tissue slice represents a portion of the tissue with wellsaved cell architecture and intercellular and space relationships between the cells. All cell types from the original tissue are present and their structural and functional heterogeneity remains intact ${ }^{2,5,13}$.

Slice preparation and incubation procedures. Slice preparation is relatively quick and easy. For example, seventy-five tissue slices can be obtained from one rat liver in about fifteen minutes. Tissue slices from different sources can be prepared in the same medium and in the same way. Slices can be obtained from different tissues from one organism, from healthy or treated animals or from different animal species. This gives an opportunity for inter-organ and inter-species comparisons. Experimental and incubation conditions for tissue slices are much easier to reproduce in comparison with perfused organs ${ }^{2,10}$.

With the liver slices, the metabolic transformation of substances which are added to the incubation medium, are slower than in suspension of hepatocytes. Both slower transport through the cell layers and the presence of different cell types in the slices probably cause this difference. The transformation rates estimated in slices are closer to the situation for perfused organs and in vivo, than metabolic changes assessed in isolated hepatocytes $^{2}$. 
Reportedly, rat liver slices can be incubated for three to five days $\mathrm{s}^{2,4,12}$. During these incubation periods, cytochromes P450 decrease, as do cytochromes P450 in isolated hepatocytes (see above). It seems that this process is slower in the slices but there are insufficient data from long lasting experiments -24 hours or longer - to confirm this. Equilibrium between specialization and dedifferentiation of the cells is controlled by the mutual ratios of members of several families of transcription factors and the decrease in cytochromes P450 is most probably linked to the absence of proper inducers in the incubation media ${ }^{1,5}$.

A period of three to five days is sufficient for gene induction studies².

Unused prepared slices can be cryopreserved and stored for later experiments. Working with slices provides opportunity for using one source for a long time, decreases the number of animals killed, and enables us to exploit clinical probes obtained peroperatively.

\section{Viability tests}

Viability should be monitored during preparation, conservation and during incubation of cells and/or slices. Several techniques can be used here. The method of choice is histological, morphological or histochemical examination. The simplest and most widely used is the Trypan blue exclusion test which is applicable to isolated cells in suspension.

Among the biochemical markers, the constant content of potassium ions in the cells or slices indicates that the plasmatic membrane is intact. Potassium content reflects the function of $\mathrm{Na}^{+} / \mathrm{K}^{+}-$ATPase. Direct measurement of $A T P$ concentration can further improve the data. A more complete picture can result from evaluation of the intracellular energy charge expressed as the ratio $[\mathrm{ATP}+\mathrm{ADP}] /[\mathrm{ATP}+\mathrm{ADP}+\mathrm{AMP}]$.

Rates of synthesis or secretion of proteins, estimation of glycogen stores or of ability of the cells to respond to hormonal stimuli can serve as additional indicators of cell activity ${ }^{4,5,10,12}$. Aminotransferase or lactatdehydrogenase isoenzymes, albumin, lipoproteins or other proteins specifically released from cells into an incubation medium can be monitored. Special indicators can be utilized to control intracellular compartmentation status $5,11,13$.

Recently, reduction of 3-(4,5-dimethylthiazol-2yl)2,5-difenyltetrazoliumbromid (so called MTT test) is widely used as a viability test. The intensity of reduction of MTT reflects the function of dehydrogenases producing both NADH and NADPH ${ }^{4,12,14}$. However, according to literature ${ }^{12}$, it does not have a direct relationship towards the function of the mitochondrial respiratory chain.

To test the metabolic functions in question, more specific tests should be used. For example, commercially available substrates should be employed as positive controls when functions of cytochrome P450 enzymes are to be investigated. The choice of proper techniques for monitoring cell viability depends on origin and use of cells and/or slices. Generally, the broader the spectrum of monitoring methods, the more reliable the results are. Often it is important to use both positive and negative controls.

\section{Subcellular fractions}

Subcellular fractions involve membrane vesicles, microsomes, cytosol and isolated biochemical entities such as proteins etc. Preparation of such subcellular fractions is relatively simple and these can be stored in a frozen state for relatively long periods of time. It is, however, necessary to add proper co-substrates and/or co-enzymes to the incubation systems when sub-cellular fractions are used ${ }^{15}$.

Microsomes allow us to study both phase I reactions and phase II biotransformations. They can be used preferentially for screening and for preparatory purposes to obtain a required amount of material, e.g. for identification of metabolites. However, important transformations catalyzed, for example, by cytosolic enzymes cannot be detected using this system. Thus, the results should be interpreted with a caution.

Alternatively, a supernatant acquired by centrifugation of tissue homogenate $(9000 \mathrm{~g})$ can be used (so called S-9 fraction). The centrifugation roughly removes nuclei, mitochondria and membrane fragments. This system is preferred especially in initial phases of studies $^{15}$.

Another in vitro system worth mention is proteins, receptors or heterologously expressed enzymes. These models are ideal for identification of enzymes responsible for concrete metabolic transformation, e.g. for identification of the cytochrome $\mathrm{P} 450$ performing a certain reaction.

\section{Our experience with hepatocyte suspensions, cultures and tissue slices}

In the Departments of Pathophysiology and Medical Chemistry and Biochemistry of the Medical Faculty, Palacký University in Olomouc, techniques using hepatocyte suspensions, confluent hepatocyte monolayers and tissue slices have been introduced over the last ten years.

Currently, primary cultures of rat, porcine, and human hepatocytes are utilized for toxicity and cell protectivity testing of natural substances, such as flavonolignans from Silybum marianum, benzo[c]phenanthridine and colchicine alkaloids. In regards to human hepatocytes we have found that the response to silibinin toxicity, generally regarded as safe at clinical doses, depends on the clinical history of the organ donor ${ }^{16}$. Hepatocyte cultures are also used to investigate possible effects of natural substances on liver cytochrome P450 expres$\operatorname{sion}^{17}$. Liver and kidney microsomal fractions and tissue slices are employed to study metabolism of natural substances too. Very important seems to be the possibility for comparing intra-species response to different xenobiotics. In particular, we have explored the metabolism of a selective cyclin-dependent kinase inhibitor bohemine 
in mouse and rat tissues. We have confirmed that even if this inhibitor can be metabolized by an NADPH-dependent, microsomal cytochrome $\mathrm{P} 450$ system, it is also an excellent substrate for NADH-dependent, liver cytosolic alcohol dehydrogenase class I that oxidizes bohemine into its corresponding carboxylic acid ${ }^{18-23}$. Moreover, bohemine proves to be a relatively good sugar acceptor in various glycosylation reactions.

\section{CONCLUSION}

In vitro systems such as cell suspensions, cell cultures, tissue slices, and subcellular fractions can be utilized for a plethora of experimental purposes. These systems should be considered as complementary and not mutually exclusive. None of them can be completely replaced by another and each is important for metabolic, toxicological and/or pharmacological studies.

\section{ACKNOWLEDGEMENTS}

Supported, in parts, by the Ministry of Education, Youth and Sports of the Czech Republic (MSM 151100001, MSM 151100003, and EU COST B17 Actions) and by the Grant Agency of the Czech Republic (303/99/P002).

\section{REFERENCES}

1. Ferrini, J.B., Pichard, L., Domergue, J., Maurel, P. (1997) Longterm primary cultures of adult human hepatocytes. Chem. Biol. Interact., 107, 31-45.

2. Bach, P. H., Vickers, A. E. M., Fisher, R., (1996) The use of tissue slices for pharmacotoxicology studies. The report and recommendations of ECVAM workshop 20. Alternat. Lab. Animals, 24, 893-923.

3. Barr, J., Weir, A. J., Brendel, K., Sipes, I. G. (1991) Liver slices in dynamic organ culture. I. An alternative in vitro technique for the study of rat hepatic drug metabolism. Xenobiotica, 21, 331-339.

4. Olinga, P., Merema, M.T., Hof, I. H. (1998) Effect of human liver source on the functionality of isolated hepatocytes and liver slices. Drug Metab. Dispos., 26, 5-11.

5. Sidelmann, U. G., Cornett, C., Tjornelund, J., Hansen, S. H. (1996) A comparative study of precision cut liver slices, hepatocytes, and liver microsomes from the wistar rat using metronidazole as a model substance. Xenobiotica, 26, 709-722.

6. LeCluyse, E., Madan, A., Hamilton, G., Carroll, K., DeHaan, R., Parkinson, A. (2000) Expression and regulation of cytochrome
P450 enzymes in primary cultures of human hepatocytes. J. Biochem. Mol. Toxicol., 14, 177-188.

7. Coundouris, J. A., Grant, M. H., Engeset, J., Petrie, J. C., Hawksworth, G. M. (1993) Cryopreservation of human adult hepatocytes for use in drug metabolism and toxicity studies. Xenobiotica, 23, 1399-1409.

8. Dvořák, Z., Adler, J., Ulrichová, J. (2000) Lidský hepatocyt II. - Kryopreservace. Cs. Slov. Farm., 49, 21-25.

9. Krumdieck, C. L., Santos, J. E. (1980) A new instrument for the rapid preparation of tissue slices. Anal. Biochem., 104, 118-123.

10. Smith, P. F., Krack, G., McKee, R. L. (1986) Maintenance of adult rat liver slices in dynamic organe culture. In Vitro Cell. Develop. Biol., 22, 706-712.

11. Olinga, P., Groen, K., Hof, H. (1997) Comparison of five incubation systems for rat liver slices using functional and viability parameters. J. Pharm. Toxicol. Methods, 38, 59-69.

12. Fisher, R. L., Shaugnessy, R. P., Jenkins, P. M. (1995) Dynamic organ culture is superior to multiwell plate culture for maintaining precision-cut tissue slices: optimization of tissue slice culture, part 1. Toxicol. Methods, 5, 99-113.

13. Kanter, R., Olinga, P., Hof, I. (1998) A rapid and simple method for cryopreservation of human liver slices. Xenobiotica, 28, 225-234.

14. Denizot, F., Lang, R. (1986) Rapid colorimetric assay for cell growth and survival. J. Immunol. Methods, 89, 271-277.

15. Rodrigues, A. D. (1994) Use of in vitro human metabolism studies in drug development. Biochem. Pharm., 48, 2147-2156.

16. Modrianský, M., Ulrichová, J., Bachleda, P., Anzenbacher, P., Anzenbacherová, E., Walterová, D., Šimánek, V. (2000) Human hepatocyte - A model for toxicological studies. Functional and biochemical characterization. Gen. Physiol. Biophys., 19, 223-235.

17. Dvořák, Z., Ulrichová, J., Modrianský, M., Maurel, P. (2000) Effect of colchicine and its derivatives on the expression of selected isoforms of cytochrome $\mathrm{P} 450$ in primary cultures of human hepatocytes. Acta Univ. Palacki. Olomuc., 143, 47-50.

18. Chmela, Z., Veselý, J., Lemr, K. (2001) In vivo metabolism of 2,6,9-trisubstituted purine-derived cyclin-dependent kinase inhibitor bohemine in mice: glucosidation as the principal metabolic route. Drug Metab. Dispos., 29, 1-10.

19. Červenková, K., Chmela, Z., Rypka, M., Lemr, K., Hanuš, J., Havlíček, L., Belejová, M., Lotková, H., Červinková, Z., Veselý, J. (2000) Metabolism of cyclin-dependent kinase inhibitor bohemine at the cellular and subcellular levels. Physiol. Res., 49, P42.

20. Modrianský, M., Dvořák, Z., Maurel, P., Ulrichová, J. (2000) Bohemine, a CDK inhibitor, induces the expression of cytochrome P450 isoforms 2E1 and 2C9. Physiol. Res., 49, P42.

21. Belejová, M., Chmela, Z., Rypka, M., Červenková, K., Veselý, J., Lukeš, J. (2001) Sledování 3 H-aktivity v orgánech myši po i.v. aplikaci 3H-značených inhibitorů CDK - srovnání s boheminem. Čs. fyziol., 50, 156.

22. Červenková, K., Veselý, J., Rypka, M., Chmela, Z., Belejová, M. (2001) Mezidruhové srovnání biotransformace syntetických purinových inhibitorů CDK metodou inkubace látek s tkáňovými řezy. XVI. Biologické dny, 3.-6. záŕí 2001, Olomouc. Sborník abstrakt, str. 114.

23. Rypka, Z., Veselý, J., Červenková, K. (2001) Kryoprezervace tkáňových řezů a jejich použití pro metabolické studie. XVI. Biologické dny, 3.-6. záríi 2001, Olomouc. Sborník abstrakt, str. 127. 